FOLIA HISTORICA CRACOVIENSIA, 21: 2015, s. 315-317

DOI: http://dx.doi.org/10.15633/fhc.1743

Józef Skrabski

Uniwersytet Papieski Jana Pawła il w Krakowie

\title{
Pracownia Inwentaryzacji i Digitalizacji Zabytków na Uniwersytecie Papieskim Jana Pawła II w Krakowie
}

Pracownia Inwentaryzacji i Digitalizacji Zabytków została utworzona w roku akademickim 2007/2008 w ramach Wydziału Historii i Dziedzictwa Kulturowego i pod opieką Instytutu Historii Sztuki i Kultury. Jej głównym zadaniem jest prowadzenie prac inwentaryzacyjnych zapoczątkowanych w 2007 roku oraz opracowywanie naukowe zabytków sakralnych, kościelnych bibliotek i archiwów w poszczególnych dekanatach diecezji Kościoła katolickiego w Polsce, w pierwszej kolejności w Archidiecezji Krakowskiej. Ogromnym wparciem działań Pracowni stała się osobista prośba Jego Eminencji Kardynała Stanisława Dziwisza z 31 marca 2008 roku do Księży i Proboszczów, w której - jak napisał - „Proszę czcigodnych Księży i wszystkie osoby sprawujące nadzór nad mieniem kościelnym o udzielenie wszelkiej pomocy grupom inwentaryzacyjnym, koniecznej do wykonania tego ogromnego zadania”.

Organizowane przez Pracownię wyjazdy inwentaryzacyjne, pod opieką doświadczonych historyków sztuki, umożliwiają studentom historii sztuki i ochrony dóbr kultury wykorzystanie w sposób praktyczny nabytej wiedzy, ćwiczenie podstawowych metod badawczych, zapoznanie się z nowoczesnymi sposobami digitalizacji różnego rodzaju dzieł sztuki, a przede wszystkim osobisty kontakt z dziełem, często zupełnie nieznanym.

Rozwój Pracowni stał się możliwy dzięki wsparciu finansowemu Uczelni z jego Wielkim Kanclerzem oraz Fundacji im. Świętej Królowej Jadwigi, dzięki której w 2010 roku uzyskano dotację z Ministerstwa Kultury i Dziedzictwa Narodowego na prace inwentaryzacyjne w powiecie niepołomickim $\mathrm{z}$ klasztorem sióstr benedyktynek w Staniątkach. Pracownia jest również zaangażowana w realizację prestiżowego grantu finansowanego w ramach Narodowego Programu Rozwoju Humanistyki Ministerstwa Nauki i Szkolnictwa Wyższego ( „Rzemiosło artystyczne w kościołach Archidiecezji Krakowskiej”). 
W planach na najbliższe miesiące pozostaje stworzenie bazy danych dla uczonych w różnych środowiskach naukowych, umożliwiającej korzystanie z bogatego zbioru ikonograficznego i opisowego oraz zdigitalizowanych jednostek archiwalnych i bibliotecznych. Wstępna zgoda Jego Ekscelencji biskupa Andrzeja Jeża umożliwia obecnie zaplanowanie w najbliższych latach podjęcia prac inwentaryzacyjnych w Diecezji Tarnowskiej. 

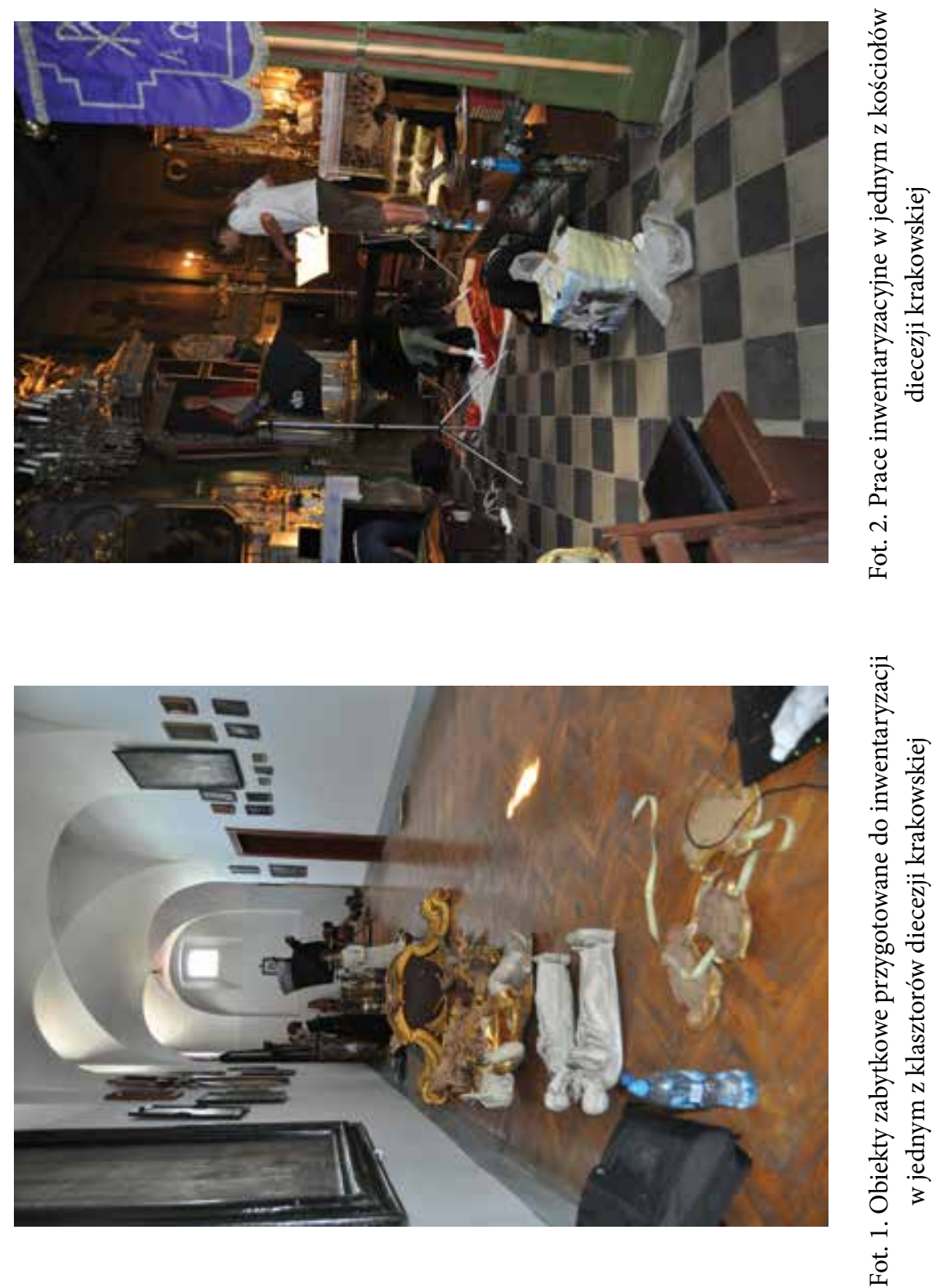